\title{
Penerapan Model Guided Inquiry Pada Pembelajaran Tematik Untuk Meningkatkan Aktivitas dan Hasil Belajar Siswa Kelas IVA SD Negeri 1 Bengkulu Tengah
}

\author{
Renny Erzaita \\ Program Magister Pendidikan Dasar Universitas Bengkulu \\ Rennyerzaita@gmail.com

\section{Irwan Koto} \\ Program Magister Pendidikan Dasar Universitas Bengkulu

\section{Puspa Djuwita} \\ Program Magister Pendidikan Dasar Universitas Bengkulu
}

\begin{abstract}
Pembelajaran tematik dengan model guided inquiry bertujuan untuk meningkatkan hasil belajar siswa dalam aspek afektif dan kognitif. Metode penelitian tindakan kelas (PTK) dilaksanakan dalam 3 siklus yang terdiri dari perencanaan, pelaksanaan, pengamatan dan refleksi. Penelitian dilakukan di kelas IVA SDN 1 Bengkulu Tengah yang terdiri dari 10 laki-laki dan 10 perempuan. Data diperoleh dari (1) pengamatan langsung kegiatan guru dalam pelaksanaan pengajaran model guided inquiry dan siswa dalam proses pembelajaran dengan guided inquiry dan (2) tes hasil belajar dalam aspek afektif dan kognitif. Data dianalisis menggunakan nilai rata-rata, ketuntasan belajar dan pengkategorian. Aktivitas guru siklus I mencapai kategori cukup, siklus II menjadi kategori baik dan siklus III meningkat dengan kategori sangat baik. Aktivitas siswa pada siklus I kategori kurang, siklus II menjadi kategori baik dan siklus III meningkat menjadi sangat baik. Hasil belajar siswa pada siklus I dengan rata-rata nilai 69,25, pada siklus II menjadi 84,75 dan meningkat lagi pada siklus III menjadi 88,75. Hasil belajar siswa secara individu pada siklus I dengan rata-rata 68,6, pada siklus II sebesar 74,75 dan pada siklus III lagi sebesar 81,85. Pada penilaian sikap spiritual dan sosial terjadi peningkatan persentase pada setiap siklusnya. Hasil penelitian ini menunjukkan bahwa dengan menerapkan model guided inquiry mampu meningkatkan proses belajar dan hasil belajar siswa.
\end{abstract}

Keywords: Kata kunci : pembelajaran tematik, model Guided Inquiry, dan hasil belajar 


\section{Pendahuluan}

Guru memegang peranan penting dalam proses pembelajaran karena proses pendidikan di Sekolah Dasar (SD) bergantung kepada guru dalam pengelolaan pembelajaran. Pendekatan dan metode guru dalam pembelajaran sangat menentukan keberhasilan siswa untuk mencapai tujuan pembelajaran. Seorang guru dituntut untuk menguasai berbagai pendekatan dan metode mengajar serta terampil dalam memanfaatkan alat peraga yang ada di lingkungan sekolah. Dengan kata lain, kualitas pembelajaran berhasil jika guru mampu memadukan secara efektif antara tuntutan kurikulum, bahan belajar, media, fasilitas dengan sumber belajar.

Sehubungan dengan itu, pemerintah terus-menerus berupaya meningkatkan kualitas pendidikan. Adapun upaya yang telah dilakukan oleh pemerintah yaitu peningkatan kualitas pendidik dan tenaga kependidikan, penyempurnaan kurikulum, dan penyediaan sarana serta prasarana. Hal tersebut dilakukan untuk mencapai tujuan pendidikan.

Tujuan pembelajaran tematik terpadu agar siswa mampu mengembangkan diri dan kompetensinya secara holistik dan bermakna. Pembelajaran tematik terpadu merupakan pembelajaran yang mengaitkan beberapa aspek baik dalam intra matapelajaran maupun antara mata pelajaran (Chusni, 2016). Menurut Sukayati dalam Kadir (2014), pembelajaran tematik terpadu membuat siswa memiliki motivasi tinggi karena pembelajaran melalui tema memudahkan siswa untuk mengetahui berbagai kegiatan dan gagasan saling terkait tanpa batas-batas pemisah antara beberapa mata pelajaran.

Berdasarkan pengalaman peneliti sebagai guru, ada lima permasalahan utama yang dihadapi guru dan siwa dalam proses pembelajaran tematik terpadu di kelas 4A SDN 1 Bengkulu Tengah : (1) Pembelajaran berpusat kepada guru (teacher center), (2) Pada saat pembelajaran guru tidak menggunakan media dan model pembelajaran yang dapat memotivasi siswa untuk belajar, (3) Kurangnya kerjasama siswa dalam kelompok, (4) Siswa kurang aktif berdiskusi dalam kelompok, dan (5) Hasil belajar masih rendah.

Solusi untuk meningkatkan proses dan hasil pembelajaran adalah dengan penerapan model pembelajaran yang dapat meningkatkan aktivitas siswa dalam pembelajaran sehingga hasil belajar lebih optimal. Salah satu alternatif model pembelajaran yang relevan dan dianggap efektif untuk mengaktifkan siswa saat belajar yaitu pembelajaran model guided inquiry. Pembelajaran dengan model guided inquiry menuntut siswa untuk berperan secara aktif selama proses pembelajaran sehingga dapat meningkatkan kemampuan siswa untuk menganalisis, mensintesis, mengevaluasi, dan menghubungkan konsep yang dipelajari dengan 
kehidupan sehari-hari meningkat dan membuat pelajaran lebih bermakna bagi siswa. Kuhlthau (2007) menyatakan bahwa dengan model pembelajaran inkuiri terbimbing, guru dapat membimbing siswa dalam meningkatkan kemampuan siswa untuk memecahkan satu permasalahan dengan menggunakan berbagai informasi. Guru berkolaborasi dan bekerja sama dengan siswa sehingga siswa dapat terlibat aktif dalam pembelajaran.

Dewi, Dantes dan Sadia (2013) menyatakan bahwa model pembelajaran inkuiri terbimbing adalah pembelajaran yang menekankan pada proses penemuan suatu konsep. Model inkuiri terbimbing dirancang sesuai dengan kemampuan siswa atau menurut tingkat perkembangan intelektualnya karena anak SD memiliki sifat yang aktif, sifat ingin tahu yang besar, terlibat dalam suatu situasi secara utuh dan reflektif terhadap suatu proses dan hasil-hasilnya yang ditemukan.

Oleh karena itu permasalahan dalam penelitian ini : yaitu 1) Bagaimanakah penerapan model langkah-langkah guided inquiry pada pembelajaran tematik yang dilakukan oleh guru untuk meningkatkan aktivitas dan hasil belajar siswa Kelas IVA SDN 1 Bengkulu Tengah? 2) Apakah penerapan model guided inquiry dapat meningkatan hasil belajar siswa pada pembelajaran tematik Kelas IVA SDN 1 Bengkulu Tengah?

\section{Metode}

Penelitian ini merupakan penelitian tindakan kelas (PTK) yang dilaksanakan di kelas IVA, PTK adalah sauatu pencermatan terhadap kegiatan belajar berupa sebuah tindakan, yang sengaja dimunculkan dan terjadi dalam sebuah kelas secara bersama. Tindakan tersebut diberikan oleh guru atau arahan dari guru yang dilakukan oleh siswa sehinggah. PTK merupakan penelitian tindakan yang dilakukan dikelas dengan tujuan memperbaiki/meningkatkan mutu praktik pembelajaran (Suhardjono dalam Asosri, 2014).

Terdapat empat tahapan yang dilakukan oleh guru dalam penelitian tindakan kelas yaitu (1) perencanaan, (2) pelaksanaan, (3) pengamatan, dan (4) refleksi (Arikunto dan Suharsimi, 2006), yang dilakukan secara bersiklus, penelitian ini telah dilakukan sebanyak tiga siklus dengan berdasarkan pada indikator keberhasilan tindakan.

Subyek penelitian adalah 20 siswa Kelas IV SDN 1 Bengkulu Tengah, terdiri dari 10 perempuan dan 10 laki-laki. Alasan peneliti melakukan penelitian di SD ini karena terdapat kesulitan belajar siswa akibat dari metode pembelajaran yang dilakukan oleh guru. 
Penelitian ini dilaksanakan di Kelas IV pada semester II tahun ajaran 2017/2018 di SDN 1 Bengkulu Tengah yang beralamat Jl. Raya Bengkulu-Curup Desa Kembang Seri Kecamatan Talang Empat. Waktu pelaksanaan penelitian dari bulan April 2018 sampai dengan bulan Mei 2018.

Tehnik Kumpulan data yang digunakan adalah observasi, tes hasil belajar, dan dokumentasi. Instrumen untuk pengumpulan data terdiri dari dari Lembar Observasi Aktivitas Guru, Lembar Observasi Aktivitas Siswa dan soal tes hasil pembelajaran IPA pada tema Kayanya Negeriku, sub tema pemanfaatan kekayaan alam di Indonesia.

Indikator keberhasilan tindakan adalah

(1). proses pembelajaran Keberhasilan aktivitas proses pembelajaran oleh guru dan siswa dikatakan baik, apabila rata-rata skor aktivitas guru dan siswa dalam pembelajaran quided inquiry berada pada rentang nilai 11-15.

(2). Indikator keberhasilan hasil belajar (pengetahuan) dalam pembelajaran quided inquiry

a) Tuntas secara individu jika siswa memperoleh nilai $\geq 70$. Dan secara klasikal $75 \%$ dari 20 siswa memiliki nilai $\geq 70$

b) Kerja kelompok dikatakan berhasil jika 75\% dari empat kelompok memperoleh nilai $\geq 70$.

\section{Hasil}

a. Deskripsi Proses pembelajaran Model Quided Inquiry siklus I, II dan III

Dalam pelaksanaan proses belajar mengajar dengan menerapkan lima langka model guided inquiry yang dilakukan guru dan siswa dikelas, pada siklus I guru belum memiliki keterampilan khusus dalam penyusunan hipotesis sehingga siswa kurang memahami cara penyusunan hipotesis dengan benar. Siklus II guru belum mampu meningkatkan peran aktif siswa dalam diskusi kelompok, sehingga proses pembelajaran tidak efektif. Kelemhan yang terjadi pada proses pembelajaran sudah diperbaiki pada siklus III.

Berdasarkan hasil analisis observasi aktivitas guru dan siswa pada ketiga siklus, dapat terlihat peningkatannya. Pada siklus I memperoleh skor rata-rata 10 dari kedua pengamat, siklus II dengan rata-rata 13,5, dan meningkat lagi pada siklus III dengan rata-rata skor 17,5.

Peningkatan aktivitas guru ketiga siklus tersebut dapat dilihat pada Gambar 1. 


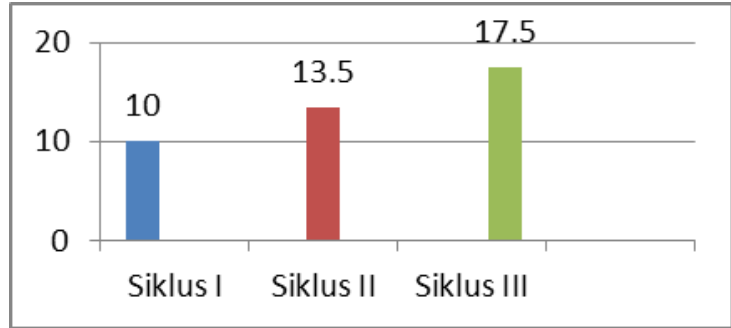

Gambar 1 Peningkatan Aktivitas Guru Siklus I, II dan II

Observasi aktivitas siswa pada ketiga siklus, dapat terlihat peningkatannya. Pada siklus I memperoleh skor rata-rata 10 dari kedua pengamat, siklus II dengan rata-rata 13,5, dan meningkat lagi pada siklus III dengan rata-rata skor 19,5. Peningkatan aktivitas siswa ketiga siklus tersebut dapat dilihat pada Gambar 2.

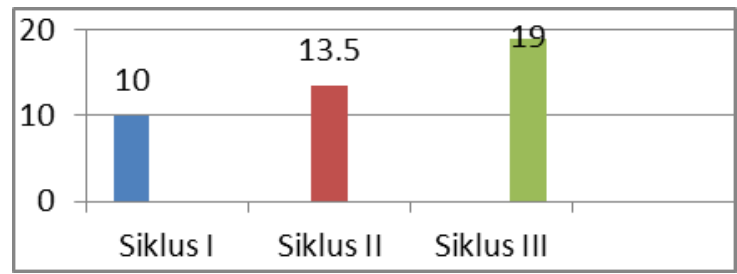

Gambar 2 Peningkatan Aktivitas Siswa Siklus I, II dan III

b. Refleksi Aktivitas Guru dan Siswa dalam Model Guided Inquiry siklus I, II dan III

Dalam menyusun hipotesis, sebaiknya guru sebelum malakukan kegiatan pembelajaran dengan model quided inquiry terutama langka-lanka menyusun hipotesis kepada siswa agar siswa lebih memahami membuat hipotesis. Siswa lebih aktif dalam kerja kelompok jika guru memebrikan motivasi dan pendampingan yang lebih dalam proses belajar.

\section{c. Belajar siswa secara berkelompok pada siklus I, II dan III}

Berdasarkan hasil analisis hasil belajar siswa secara berkelompok pada ketiga siklus, dapat terlihat peningkatannya. Pada siklus I memperoleh skor rata-rata 69,25 dari kedua pengamat, siklus II dengan rata-rata 84,75 dan meningkat lagi pada siklus III dengan rata-rata skor 88,75 . Peningkatan hasil belajar siswa secara berkelompok pada ketiga siklus tersebut dapat dilihat pada Gambar 3.

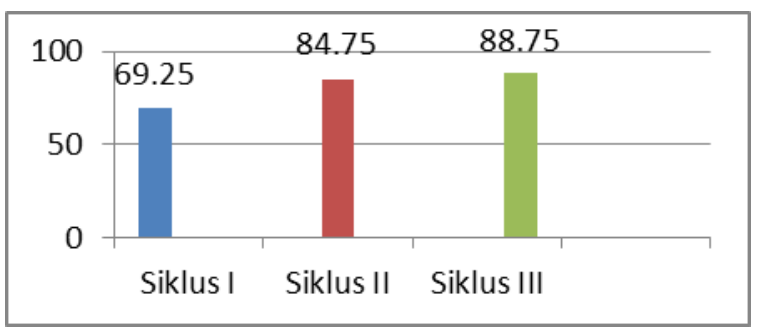

Gambar 3 Peningkatan hasil belajar siswa secara berkelompok 


\section{d. Hasil belajar siswa secara individu pada siklus I, II dan III}

Berdasarkan hasil analisis nilai tes hasil belajar individu siswa pada ketiga siklus, dapat terlihat peningkatannya. Pada siklus I memperoleh skor rata-rata 68,60 , siklus II dengan rata-rata 74,75, dan meningkat lagi pada siklus III dengan rata-rata skor 81,15. Peningkatan nilai tes hasil belajar individu siswa pada ketiga siklus tersebut dapat dilihat pada Gambar 4.

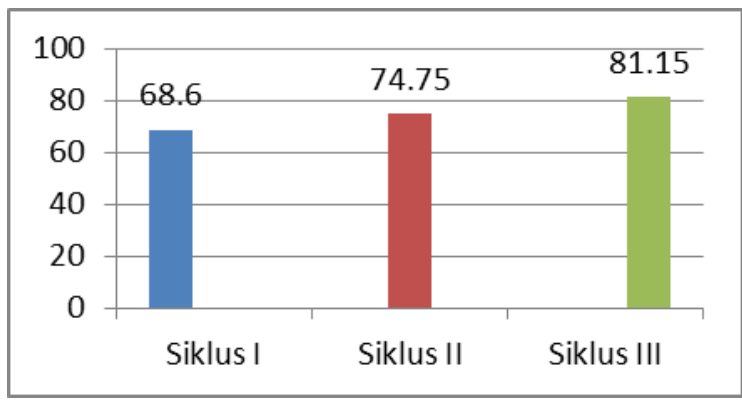

Gambar 4 Peningkatan nilai rata-rata siswa

Peningkatan persentase ketuntasan belajar klasikal

Berdasarkan hasil hitung persentase ketuntasan belajar klasikal hasil belajar individu siswa pada ketiga siklus, dapat terlihat peningkatannya. Pada siklus I memperoleh persentase sebesar $45 \%$, siklus II dengan persentase sebesar $75 \%$, dan meningkat lagi pada siklus III dengan persentase sebesar 90\%. Peningkatan persentase ketuntasan belajar klasikal ketiga siklus dapat dilihat pada Gambar 5 .

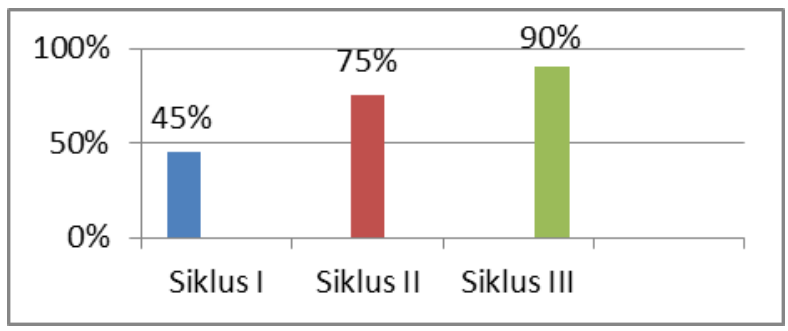

Gambar 5 Peningkatan persentase ketuntasan belajar klasikal

\section{Pembahasan}

\section{a. Penerapan langkah-langkah pembelajaran model quided inquiry}

Pada siklus I jumlah skor aktivitas guru yang dilakukan pengamat 1 dengan skor 10, pengamat 2 dengan jumlah skor 10, sehingga jumlah skor aktivitas guru pada siklus I yaitu 20 dengan nilai rata-rata skor penilaian 10 dengan kategori cukup. Pada siklus II jumlah skor aktivitas guru yang dilakukan pengamat 1 dengan skor 14, pengamat 2 dengan jumlah skor 13, sehingga jumlah skor aktivitas guru pada siklus II yaitu 27 dengan nilai rata-rata skor penilaian 13,5 dengan kategori baik. Pada siklus III jumlah skor aktivitas guru yang dilakukan pengamat 1 dengan skor 18, pengamat 2 dengan jumlah skor 20, sehingga jumlah skor 
aktivitas guru pada siklus III yaitu 38 dengan nilai rata-rata skor penilaian 17,5 dengan kategori sangat baik.

Peningkatan pada siklus I dengan siklus II sebesar 3,5. Peningkatan siklus II dengan siklus III sebesar 4. Dari tiga siklus dengan menerapkan model guided inquiry, seluruhnya mampu memberikan peningkatan skor. Hal ini berarti penerapan model guided inquiry, mampu meningkatkan kualitas proses pembelajaran, dapat dilihat pada tabel 1

\begin{tabular}{|c|c|c|c|c|}
\hline \multirow[b]{2}{*}{ No. } & \multirow[b]{2}{*}{ Sintak } & \multicolumn{3}{|c|}{ Guru } \\
\hline & & $\begin{array}{c}\text { siklus } \\
1\end{array}$ & $\begin{array}{c}\text { siklus } \\
\text { II }\end{array}$ & $\begin{array}{c}\text { siklus } \\
\text { III }\end{array}$ \\
\hline 1 & $\begin{array}{l}\text { Siswa aktif berdiskusi untuk mengidentifikasi } \\
\text { masalah }\end{array}$ & 2 & 3 & 3,5 \\
\hline 2 & $\begin{array}{l}\text { Siswa terlibat aktif memberikan pendapat } \\
\text { dalam menyusun hipotesis }\end{array}$ & 1 & 2,5 & 3,5 \\
\hline 3 & $\begin{array}{llll}\text { Siswa aktif melakukan } & \text { percobaan dalam } \\
\text { kelompok } & & \\
\end{array}$ & 2 & 2 & 3,5 \\
\hline 4 & $\begin{array}{l}\text { Siswa dibimbing untuk melakukan analisis } \\
\text { data }\end{array}$ & 2 & 3 & 3 \\
\hline 5 & Siswa dibimbing merumuskan kesimpulan & 3 & 3 & 4 \\
\hline & Total & 10 & 13,5 & 17,5 \\
\hline & Kriteria & Cukup & Baik & $\begin{array}{c}\text { sangat } \\
\text { baik }\end{array}$ \\
\hline
\end{tabular}

Pada aktivitas siswa, siklus I jumlah skor aktivitas siswa yang dilakukan pengamat 1 dengan skor 10, pengamat 2 dengan jumlah skor 10, sehingga jumlah skor aktivitas guru pada siklus I yaitu 20 dengan nilai rata-rata skor penilaian 10 dengan kategori cukup. Pada siklus II jumlah skor aktivitas siswa yang dilakukan pengamat 1 dengan skor 14, pengamat 2 dengan jumlah skor 13 sehingga jumlah skor aktivitas siswa pada siklus II yaitu 27 dengan nilai rata-rata skor penilaian 13,5 dengan kategori baik. Pada siklus III jumlah skor aktivitas siswa yang dilakukan pengamat 1 dengan skor 18 , pengamat 2 dengan jumlah skor 20, sehingga jumlah skor aktivitas siswa pada siklus III yaitu 38 dengan nilai rata-rata skor penilaian 19 dengan kategori sangat baik. Peningkatan rata-rata pada siklus I dengan siklus II sebesar 3,5. Peningkatan siklus II dengan siklus III sebesar 5.5. dapat dilihat pada tabel 2 


\begin{tabular}{|c|c|c|c|c|}
\hline \multirow[b]{2}{*}{ No. } & \multirow[b]{2}{*}{ Sintak } & \multicolumn{3}{|c|}{ Guru } \\
\hline & & $\begin{array}{c}\text { siklus } \\
1\end{array}$ & $\begin{array}{l}\text { siklus } \\
\text { II }\end{array}$ & $\begin{array}{c}\text { siklus } \\
\text { III }\end{array}$ \\
\hline 1 & $\begin{array}{l}\text { Siswa aktif berdiskusi untuk mengidentifikasi } \\
\text { masalah }\end{array}$ & 2 & 3 & 3,5 \\
\hline 2 & $\begin{array}{l}\text { Siswa terlibat aktif memberikan pendapat } \\
\text { dalam menyusun hipotesis }\end{array}$ & 1 & 2,5 & 3,5 \\
\hline 3 & $\begin{array}{l}\text { Siswa aktif melakukan percobaan dalam } \\
\text { kelompok }\end{array}$ & 2 & 2,5 & 4 \\
\hline 4 & $\begin{array}{l}\text { Siswa dibimbing untuk melakukan analisis } \\
\text { data }\end{array}$ & 2 & 3 & 4 \\
\hline 5 & Siswa dibimbing merumuskan kesimpulan & 3 & 3 & 4 \\
\hline & Total & 10 & 13,5 & 19 \\
\hline & Kriteria & Cukup & Baik & $\begin{array}{l}\text { sangat } \\
\text { baik }\end{array}$ \\
\hline
\end{tabular}

Berdasarkan paparan tersebut membuktikan bahwa dengan menerapkan model pembelajaran inkuiri terbimbing dapat meningkatkan aktivitas guru dan siswa dalam membimbing siswa sesuai dengan tujuan belajar yang dikemukakan Bruner (Suyono \& Hariyanto, 2016) bahwa guru harus memandu siswa untuk mendapatkan basis pengetahuannya sendiri. Penerapan model pembelajaran inkuiri juga dapat meningkatkan aktivitas siswa dalam mencari pengetahuan sendiri. Hal ini sesuai dengan hasil penelitian yang dilakukan Suduc, Bizoi dan Gorghiu (2015) yang mengemukakan bahwa pembelajaran inkuiri membuat siswa aktif dengan menggunakan yang melibatkan eksplorasi, membuat pertanyaan, membuat penemuan, dan pengujian penemuan untuk mencari pemahaman baru.

Pencapaian ini senada dengan Suastra (2009) dalam jurnal (santiasih, dkk 2013) menyatakan bahwa pembelajaran sains berdasarkan model inkuiri adalah suatu strategi pembelajaran yang berpusat pada siswa di mana kelompok-kelompok siswa dihadapkan pada suatu persoalan atau mencari jawaban terhadap pertanyaanpertanyaan melalui prosedur yang direncanakan secara jelas.

Dari tiga siklus dengan menerapkan model guided inquiry, seluruhnya mampu memberikan peningkatan skor. Hal ini berarti penerapan model guided inquiry, mampu meningkatkan kualitas aktivitas siswa dalam proses pembelajaran tematik.

\section{b. Penerapan Model Hasil belajar siswa}

(1) Hasil belajar sikap siswa 
Berdasarkan hasil pengamatan sikap siswa selama proses belajar mengajar dengan penerapan model quided inquiry pada pembelajaran tematik yang telah dilaksanakan dalam 3 siklus dimana setiap siklus dilakukan oleh dua orang pengamat, diperoleh gambaran bahwa sikap siswa dalam proses pembelajaran telah meningkat. Berdasarkan analisis yang dilakukan terhadap lembar sikap siswa tampak bahwa terjadi peningkatan rata-rata aktivitas siswa dalam pelaksanaan pembelajaran pada siklus I, II dan siklus III.

Untuk sikap religius pada siklus I,II dan III jumlah persentase pada aspek berdoa yang memiliki predikat sangat baik yaitu $45 \%, 67,5 \%$ dan $75 \%$. Persentase yang memiliki predikat baik 55\%, 32,5\% dan 25\%. Aspek berprilaku bersyukur pada siklus I,II dan III jumlah persentase yang memiliki predikat sangat baik yaitu $52,5 \%, 72,5 \%$ dan $75 \%$. persentase predikat baik $47,5 \%, 27,5 \%$ dan $25 \%$.

Sikap sosial aspek kerjasama yang memiliki predikat sangat baik pada siklus I,II dan III yaitu 25\%, 50\% dan 62,5\%. Predikat baik 52,5\%, 35\% dan 37,5\%. Predikat cukup $22,5 \%, 15 \%$ dan $0 \%$. Pada siklus I,II dan III untuk aspek percaya diri yang memiliki predikat sangat baik $25 \%, 47,5 \%$ dan $70 \%$. predikat baik $50 \%, 37,5 \%$ dan 30\%. predikat Cukup 25\%, 15\% dan 0\%.

Peningkatan pada sikap spiritual pada aspek berdoa dan rasa bersyukur terjadi peningkatan di setiap siklusnya. Pada sikap sosial aspek kerjasama dan percaya diri predikat cukup atau belum tuntas pada siklus I dan II masih ada bebrapa siswa, di siklus III semua siswa sudah tuntas 100\%. dapat diliat pada tabel 3

\begin{tabular}{|c|c|c|c|c|}
\hline \multirow[t]{2}{*}{ Aspek yang dinilai } & \multirow[b]{2}{*}{ Predikat } & \multicolumn{3}{|c|}{ rata-rat persentase \% } \\
\hline & & siklus I & siklus II & siklus III \\
\hline \multirow{4}{*}{ Berdoa } & SB & 45 & 67,5 & 75 \\
\hline & B & 55 & 32,5 & 25 \\
\hline & $\mathrm{C}$ & 0 & 0 & 0 \\
\hline & $\mathrm{K}$ & 0 & 0 & 0 \\
\hline \multirow{4}{*}{ berprilaku syukur } & SB & 52,5 & 72,5 & 75 \\
\hline & B & 47,5 & 27,5 & 25 \\
\hline & $\mathrm{C}$ & 0 & 0 & 0 \\
\hline & $\mathrm{K}$ & 0 & 0 & 0 \\
\hline \multirow{5}{*}{ Kerjasama } & SB & 25 & 50 & 62,5 \\
\hline & B & 52,5 & 35 & 37,5 \\
\hline & $\mathrm{C}$ & 22,5 & 15 & 0 \\
\hline & $\mathrm{K}$ & 0 & 0 & 0 \\
\hline & SB & 25 & 47,5 & 70 \\
\hline
\end{tabular}


Penerapan Model Guided Inquiry Pada Pembelajaran Tematik Untuk Meningkatkan Aktivitas dan Hasil Belajar Siswa Kelas IVA SD Negeri 1 Bengkulu Tengah

\begin{tabular}{|c|c|c|c|c|}
\hline Percaya diri & $\mathrm{B}$ & 50 & 37,5 & 30 \\
\cline { 2 - 5 } & $\mathrm{C}$ & 25 & 15 & 0 \\
\cline { 2 - 5 } & $\mathrm{K}$ & 0 & 0 & 0 \\
\hline
\end{tabular}

Dari tiga siklus dengan menerapkan model guided inquiry, seluruhnya mampu memberikan peningkatan persentase. Hal ini berarti penerapan model guided inquiry, mampu meningkatkan kualitas proses pembelajaran tematik pada kelas IVA 1SDN 1 Bengkulu Tengah.

(2) Hasil belajar Kognitif siswa

Dalam proses pembelajaran dengan menggunakan penerapan pendekatan quided inqury melalui diskusi kelompok terlihat bahwa aktivitas guru dan siswa sangat baik. Hal ini dapat dilihat dari keaktifan siswa dalam melakukan penemuan dengan diskusi kelompok sedangkan guru bertindak sebagai fasilitator dan motivator. Ini berarti bahwa siswalah yang aktif dalam mencari dan menemukan serta memecahkan masalah dan guru hanya memberikan motivasi dan memfasilitasi kegiatan siswa, dapat dilihat pada tebel 4

\begin{tabular}{|l|l|c|c|c|}
\hline \multirow{2}{*}{ No. Sintak } & \multicolumn{3}{|c|}{ rat-rata skor } \\
\cline { 3 - 5 } & & siklus & siklus & siklus \\
II & III \\
\hline 1. & Orientasi dan merumuskan masalah & 12,5 & 16 & 18,75 \\
\hline 2. & Menyusun hipotesis & 12,5 & 15,75 & 15,5 \\
\hline 3. & Melakukan percobaan & 16,25 & 20 & 20 \\
\hline 4. & $\begin{array}{l}\text { Mengumpulkan dan melakukan analisis } \\
\text { data }\end{array}$ & 14,25 & 17,5 & 18,75 \\
\hline 5. & Membuat kesimpulan & 13,75 & 15,5 & 15,75 \\
\hline & Total hasil belajar siswa & 69,25 & 84,75 & 88,75 \\
\hline \multicolumn{2}{|c|}{ Kriteria } & Cukup & Baik & Baik \\
\hline
\end{tabular}

Peningkatan kualitas proses pembelajaran tematik diikuti dengan peningkatan hasil belajar siswa dikarenakan penerapan melalui pendekatan model quided inqury diikuti secara aktif oleh siswa selama proses pembelajaran berlangsung yaitu 3 siklus. Hasil belajar siswa secara individu dan persentase ketuntasan belajar secara klasikal yang diperoleh dari kegiatan pembelajaransecara klasikal dari siklus I,II dan III, dapat dilihat pada tabel 5. 


\begin{tabular}{|c|c|c|c|c|}
\hline \multirow{2}{*}{ no } & \multirow{2}{*}{ Evaluasi hasil belajar } & \multicolumn{3}{|c|}{ Data hasil } \\
\cline { 3 - 5 } & & siklus I & siklus II & siklus III \\
\hline 1 & Rata-rata & $68,60 \%$ & $74,75 \%$ & 81,15 \\
\hline 2 & nilai $\geq 70$ (tuntas) & 9 orang & 15 orang & 18 orang \\
\hline 3 & nilai $<70$ (belum tuntas) & 11 orang & 5 orang & 2 orang \\
\hline 4 & ketuntasan klasikal & $45 \%$ & $75 \%$ & $95 \%$ \\
\hline
\end{tabular}

Menerapkan model pembelajaran quided inquiry dapat meningkatkan pemahaman siswa. Peningkatan tersebut terlihat dari hasil tes siswa pada setiap akhir siklus. Hal tersebut membuktikan bahwa model pembelajaran inkuiri terbimbing dapat meningkatkan pemahaman siswa. Hal ini sesuai dengan Dewi, Dantes, dan Sadia (2013) yang menyimpulkan bahwa model pembelajaran inkuiri terbimbing dapat meningkatkan hasil belajar siswa. Hasil belajar dalam hal ini berupa pemahaman siswa terhadap konsep yang sudah diajarkan.

\section{Kesimpulan}

Berdasarkan hasil penelitian dan pembahasan, dapat disimpulkan sebagai berikut:

1. Guru sebagai peneliti telah menerapkan lima langka guided inquiry, namun pada penyusunan hipotesisi guru belum memiliki keterampilan khusus. guru belum mamapu meningkatkan peran aktif siswa dalam diskusi kelompok.

2. Guru sebagai peneliti telah menerapkan model guided inquiry sehingga aktivitas belajar siswa meningkat, namun kemampuan siswa dalam menyusun hipotesis dan keaktifan dalam diskusi kelompok belum meningkat.

3. Guru sebagai peneliti telah menerapkan model guided inquiry sehingga hasil belajar siswa meningkat dengan indikator persentase ketuntasan belajar secara klasikal 45\% (siklus I), 75\% (siklus II) dan 95\% (siklus III).

\section{Saran}

1. Mayoritas siswa mengalami kesulitan dalama membuat hipotesis, oleh karena itu untuk peneliti berikutnya disarankan untuk memberi penjelasan kepada siswa tentang langka-langka penyusunan hipotesis serta melatih siswa membuaat hipotesis dengan memberikan beberapa contoh.

2. Siswa kurang aktif melakukan percobaan karena belum terbiasa bekerjasama dalam kelompok, agar siswa terlatih belajar berdiskusi dalam kelompok kecil atau kelompok besar, maka perlu bimbingan secar intensif.

3. Masih banyak siswa mendapatkan nilai rendah dalam menyelesaikan evaluasi baik secara kelompok atau individu karena kurangnya motivasi belajar. Untuk 
Penerapan Model Guided Inquiry Pada Pembelajaran Tematik Untuk Meningkatkan Aktivitas dan Hasil Belajar Siswa Kelas IVA SD Negeri 1 Bengkulu Tengah

itu agar dapat menumbuhkan motivasi belajar siswa perlu pemilihan media belajar yang bervarias

\section{Referensi}

Arikunto dan sulami. 2006. Penelitian Tindakan Kelas. Jakarta: Bumi Aksara Asrori, M. 2014. Penelitian Tindakan Kelas. Bandung: CV. Wacana Prima.

Chusni Minan,., Astuti. M \& Dhuta.S. 2015. Penerapan Kurikulum 2013 pada Pembelajaran Tematik Saintifik dengan Media Lingkungan Sekolah untuk Meningkatkan Keterampilan Proses Sains Siswa. Jurnal Pengajaran MIPA, Volume 20, Nomor 2.

Dewi, N. L., Dantes, N., \& Sadia, I. W. 2013. Pengaruh Model Pembelajaran Inkuiri Terbimbing Terhadap Sikap Ilmiah Dan Hasil Belajar IPA. e-Journal Program Pascasarjana Universitas Pendidikan Ganesha Jurusan Pendidikan Dasar (Volume 3 Tahun 2013).

Kadir, H, A. 2014. Pembelajaran Tematik. Jakarta: PT. Rajagrafindo

Kemdikbud. 2016. Panduan Pembelajaran Tematik Terpadu.

Kementerian Pendidikan dan Kebudayaan RI. Permendikbud Nomor 65 Tahun 2013 Tentang Standar Proses. Jakarta.

Kultahu, C C., Maniotes, 1 K., \& Caspari, A K. (2007). Guided Inquiry Learning In The 21st Century. London: Libraries Unlimited

Santiasih,. Marhaeni, dan Tika. 2013. Pengaruh Model Pembelajaran Inkuiri Terbimbing Terhadap Sikap Ilmiah dan Hasil Belajar IPA Siswa Kelas V SDN 1 Kerobokan Kecamatan Kuta Utara Kabupaten Badung Tahun Pelajaran 2013/2014. e-Journal Program Pascasarjana Universitas Pendidikan Ganesha.

Sudjana, N. 2014. Penelitian Hasil Proses Belajar Mengajar. Bandung: Remaja Rosdakarya

Suduc, A. M., Bizoi, M., \& Gorghiu, G. 2015. Inquiry Based Science Learning in Primary Education. Procedia - Social and Behavioral Sciences: 6th World conference on Psychology Counseling and Guidance. 474 - 479. ELSEVIER

Suyono, \& Hariyanto. 2016. Belajar dan Pembelajaran. Bandung: PT Remaja Rosda Karya. 